JURNAL PANGKAJA PROGRAM PASCASARJANA UNIVERSITAS HINDU NEGERI I GUSTI BAGUS SUGRIWA DENPASAR
Vol.24, No. 2, September 2021

ISSN : 1412-7474 (Cetak)

ISSN : 2623-2510 (Online)

http://ejournal.ihdn.ac.id

\title{
PERSEPSI GURU AGAMA HINDU TERHADAP KENAKALAN SISWA SAAT PEMBELAJARAN DARING (Studi Kasus di SMAS Dharma Praja Denpasar)
}

\author{
Kompyang Sri Wahyuningsih \\ Universitas Hindu Negeri I Gusti Bagus Sugriwa Denpasar \\ Email: kompyangsriwahyuningsih@gmail.com
}

\begin{abstract}
ABSTRAK
Pembelajaran daring saat ini masih diberlakukan di setiap jenjang pendidikan di Indonesia guna mencegah penyebaran virus Covid-19 yang semakin merebak di beberapa daerah tidak kecuali Bali dan Denpasar sebagai pusat roda perekonomian. Salah satu Sekolah Menegah Atas yang menerapkan pembelajaran daring adalah SMAS Dharma Praja Denpasar. Hal ini menimbulkan berbagai permasalahan di kalangan siswa yaitu pola tingkah laku yang kurang mencerminkan kesopanan dan karakter mulia seperti tidak berminat untuk belajar secara daring, tidak serius mengikuti pembelajaran daring, bahkan melakukan halhal yang cenderung negatif atau nakal dengan berbagai faktor penyebab. Fenomena ini menarik untuk diteliti dalam ranah pendidikan agama Hindu.

Tujuan dari penelitian ini adalah mengungkap persepsi guru agama Hindu terhadap kenakalan siswa saat pembelajaran daring. Rancangan dalam penelitian ini adalah studi kasus fenomenologis dengan pendekatan kualitatif. Metode pengumpulan data dalam penelitian ini adalah observasi, wawancara dan studi kepustakaan. Hasil penelitian terhadap persepsi guru agama Hindu di SMAS Dharma Praja Denpasar terkait dengan kenakalan siswa saat pembelajaran daring yaitu: 1) Kenakalan siswa adalah pelanggaran aturan sekolah dan tingkah laku menyimpang sehingga dapat merugikan siswa lain dan membuat suasana belajar menjadi tidak kondusif; 2) Kategori kenakalan siswa dibagi menjadi 2 bagian yaitu kenakalan serius dan perilaku mengganggu. Kenakalan serius dipersepsikan meliputi : mencuri dan membolos; sedangkan perilaku mengganggu meliputi: tidak memperhatikan penjelasan guru, mencontek dan tidak patuh terhadap arahan guru; 3) Terdapat empat penyebab kenakalan siswa yaitu: kurangnya perhatian orang tua (pendidikan moral dan dukungan ekonomi), metode pembelajaran guru yang kurang bervariasi (monoton), bahasa yang sulit dipahami siswa dan materi pelajaran terlalu banyak; 4) Cara mengatasi kenakalan siswa yaitu: teguran verbal, perhatian khusus, memanipulasi pemberian tugas, memberikan aktivitas pengganti, memberikan pemahaman khusus, memberikan kisi-kisi belajar, berkomunikasi dengan orang tua, memberikan peraturan, memberikan pilihan baik-buruk, pembiasan, memberikan pengalaman gagal, memberikan motivasi, berkomunikasi secara pribadi dengan siswa dan dikembalikan kepada orang tua.
\end{abstract}

Kata Kunci: persepsi, guru, kenakalan siswa, pembelajaran daring

\section{ABSTRACT}

Online learning is currently still being implemented at every level of education in Indonesia in order to prevent the spread of the Covid-19 virus which is increasingly 
spreading in several areas, including Bali and Denpasar as the center of the economy. One of the senior high schools that implement online learning is SMAS Dharma Praja Denpasar. This raises various problems among students, namely behavior patterns that do not reflect politeness and noble character such as not being interested in online learning, not taking online learning seriously, even doing things that tend to be negative or naughty with various causative factors. This phenomenon is interesting to study in the realm of Hindu religious education.

The purpose of this study was to reveal the perception of Hindu religious teachers on student misbehavior during online learning. The design in this research is a phenomenological case study with a qualitative approach. Data collection methods in this study were observation, interviews and literature study. The results of the study on the perceptions of Hindu religious teachers at SMAS Dharma Praja Denpasar related to student delinquency during online learning, namely: 1) Student delinquency is a violation of school rules and deviant behavior so that it can harm other students and make the learning atmosphere not conducive; 2) The category of student delinquency is divided into 2 parts, namely serious delinquency and disruptive behavior. Serious delinquency is perceived to include: stealing and truancy; while disruptive behavior includes: not paying attention to the teacher's explanation, cheating and disobeying the teacher's directions; 3) There are four causes of student delinquency, namely: lack of parental attention (moral education and economic support), teacher learning methods that are less varied (monotonous), language that is difficult for students to understand and too much subject matter; 4) How to overcome student delinquency, namely: verbal reprimand, special attention, manipulating assignments, providing substitute activities, providing special understanding, providing learning grids, communicating with parents, giving rules, giving good and bad choices, refraction, providing experience fail, provide motivation, communicate privately with students and are returned to parents.

Keywords: perception, teacher, student delinquency, online learning

\section{PENDAHULUAN}

Pembelajaran daring sebagai dampak dari pandemi Covid-19 masih diterapkan di berbagai sekolah di setiap satuan pendidikan, tidak kecuali SMA/SMK. Komponen pendidikan mulai dari guru, siswa dan orang tua siswa diharapkan dapat beradaptasi dengan pola pembelajaran daring atau online yang dilaksanakan secara tiba-tiba guna mengantisipasi penyebaran Covid-19. Media dan metode pembelajaran yang dipersiapkan oleh guru diarahkan mampu menciptakan daya tarik sehingga para siswa dapat merasakan "suasana kelas" walaupun belajar dari rumah. Setiap guru memiliki seni dalam mengajar dan hal ini akan direspon oleh setiap siswa dengan karakter yang beragam dalam satu kelas. Guru Agama Hindu tidak hanya menjelaskan materi pembelajaran namun juga menyelipkan nilainilai moral yang terkait dengan materi yang dibahas seperti nilai kejujuran, tanggung jawab, toleransi dan nilai moral lainnya sehingga siswa dapat memecahkan berbagai permasalahan yang dihadapi.

Perbuatan mencorat-coret layar/screen saat pembelajaran online berlangsung dengan menggunakan plat form zoom merupakan salah satu contoh adanya perilaku negatif yang dilakukan oleh siswa. Seorang siswa membuat gaduh dan mengganggu konsentrasi siswa lainnya sehingga pembelajaran menjadi tidak kondusif. Hal ini merupakan salah satu contoh nyata yang penulis alami saat observasi secara virtual di SMAS Dharma Praja Denpasar.

Permasalahan yang dihadapi guru tidak hanya dari aspek perilaku siswa, peneliti juga mencatat beberapa kejadian tidak disiplin siswa saat pembelajaran daring seperti terlambat masuk/join ke dalam kelas virtual, saat video conference sedang berlangsung, siswa yang 
menyalakan speaker saat tidak berbicara sehingga suara yang mengganggu terdengar, bahkan terdapat siswa yang jarang hadir saat pembelajaran daring. Perilaku ini membawa dampak mengganggu pembelajaran.

Perilaku mengganggu merupakan kegiatan yang dapat menyulitkan guru dan berpengaruh pada proses belajar mengajar. Menurut Arbuckle \& Little (2004 : 19) perilaku mengganggu yaitu segala perilaku yang dilakukan oleh siswa untuk mengambil kesempatan yang kurang baik dalam pembelajaran. Kenakalan siswa dapat disebabkan oleh penolakan emosional, atau faktor lingkungan. Penelitian ini berfokus untuk mengungkap persepsi guru Agama Hindu terhadap kenakalan siswa saat pembelajaran daring. Persepsi tersebut meliputi tanggapan, pandangan, pendapat tentang kenakalan siswa, penyebab kenakalan siswa dan upaya atau tindakan yang dilakukan oleh guru Agama Hindu terhadap kenakalan tersebut.

Penelitian ini menggunakan pendekatan kualitatif, dengan rancangan studi kasus fenomenologis. Sumber data dalam penelitian ini yaitu guru Agama Hindu di SMAS Dharma Praja Denpasar. Data yang dikumpulkan yaitu data fisik, lisan, aktivitas dan tertulis. Prosedur pengumpul data yang digunakan yaitu melalui teknik observasi, wawancara mendalam dengan teknik tidak terstruktur sehingga memungkinkan bagi informan untuk mengungkapkan pandangan terhadap suatu fenomena yaitu kenakalan siswa saat pembelajaran daring secara lebih mendalam. Analisis data yang digunakan yaitu analisis data fenomenologis yakni melihat fenomena atau gejala sosial yang ada yakni situasi pembelajaran di kelas virtual kemudian memperhatikan, mengkaji, menganalisis, dan menyimpulkan fenomena tersebut yakni kenakalan siswa saat pembelajaran daring berlangsung. Prosedur analisis data yaitu reduksi data, penyajian data dan penarikan kesimpulan.

\section{PEMBAHASAN \\ Persepsi Guru Tentang Kenakalan Siswa}

Guru Agama Hindu di SMAS Dharma Praja Denpasar berpendapat bahwa kenakalan siswa adalah perilaku menyimpang dan melanggar peraturan sekolah yang dilakukan oleh siswa, sehingga mengganggu suasana belajar dan merugikan individu lain. Hal itu senada dengan pernyataan Willis (2005) yang menyatakan bahwa kenakalan remaja adalah perbuatan para remaja yang bertentangan dengan hukum, agama dan norma-norma di masyarakat (kriminal, anti sosial, melanggar aturan) sehingga berakibat merugikan orang lain, ketenteraman umum dan juga merusak dirinya sendiri.

Sejalan dengan hasil wawancara penulis terhadap Guru Agama Hindu di SMAS Dharma Praja Denpasar, Ayu Pande (wawancara 17 Juni 2021) mengungkapkan bahwa perbuatan anti sosial itu tercermin dari dirugikannya individu atau siswa karena terganggu dengan suasana kelas yang diperbuat oleh siswa lainnya. Sedangkan melanggar aturan yakni peraturan sekolah yang telah disepakati bersama dilanggar baik disengaja untuk mencari perhatian maupun tidak disengaja karena lupa dan faktor lainnya. Merujuk pada pendapat tersebut, siswa yang melanggar peraturan sekolah dinyatakan bahwa siswa tersebut melanggar statusnya sebagai siswa sehingga dampaknya mengganggu proses belajar dari individu lainnya di kelas. Pendapat lain diungkapkan oleh Sarwono (2001) yang menterjemahkan kenakalan (delinquency) dengan menyerap arti kata dalam bahasa Belanda yaitu baldadigheid yang berarti semua perbuatan yang berlawanan dengan ketertiban umum, ditujukan pada orang, binatang dan barang yang dapat menimbulkan bahaya, kerugian dan kesusahan.

Selanjutnya kenakalan siswa dipahami dari sudut pandang kenakalan serius. Kenakalan serius ini timbul dari hal sederhana misalnya tangan sengaja mengklik tombol atau fitur tertentu saat video conference berlangsung sehingga mengundang canda tawa yang tidak pada tempatnya untuk menarik perhatian guru dan teman sekelas. Selain itu siswa 
mengatakan hal-hal diluar materi yang dibahas sehingga dapat dikatakan perbuatan tersebut jauh dari norma etika dan kesopanan. Perilaku menyimpang ini terjadi karena kurangnya perhatian dari orang tua di rumah sehingga ingin mencari perhatian di sekolah saat pembelajaran daring berlangsung. Jika hal ini tidak ditangani dengan baik dan berkesinambungan oleh guru dan orang tua maka akan berdampak buruk bagi perkembangan moral siswa dan siswa akan mudah terjerumus ke dalam pergaulan negatif. Hal itu sesuai dengan pendapat Reed dkk (2009) yang menyatakan bahwa perilaku kenakalan siswa remaja yang berpotensi mengacaukan yaitu gang activities (aktivitas geng), alcohol and drug abuse (penyalah gunaan narkoba) dan serious property delinquent (kenakalan yang bersifat serius).

Merujuk pada hal tersebut pernyataan guru Agama Hindu di SMAS Dharma Praja Denpasar mengenai kenakalan siswa juga dapat dikategorikan dalam perilaku mengganggu. Guru Agama Hindu di SMAS Dharma Praja Denpasar merinci bentuk perilaku mengganggu meliputi: tidak memperhatikan penjelasan guru, mencontek, mengalihkan pembicaraan dari materi pelajaran atau diskusi dan tidak patuh terhadap arahan guru. Kenakalan serius siswa meliputi perilaku membolos.

\section{Mencontek}

Guru Agama Hindu di SMAS Dharma Praja Denpasar berpendapat bahwa salah satu perilaku negatif siswa dalam proses pembelajaran adalah mencontek. Menyalin jawaban dari teman lainnya merupakan contoh sederhana dari mencontek. Hal ini dapat mengaburkan hasil tes sehingga guru kesulitan menentukan siapa siswa yang telah mampu menguasai kompetensi dan siswa yang belum mencapai kompetensi. Selain itu, perilaku ini membuat siswa tidak mandiri dalam belajar dan mudah tergantung pada siswa yang lain sehingga membuat siswa tersebut malas belajar. Hal ini sesuai dengan pernyataan Danielsen, dkk (2006) yang menyatakan bahwa perilaku mencontek merupakan tindakan yang tidak pantas dilakukan di dalam lingkungan akademis. Artinya bahwa perilaku ini dapat membuat siswa menjadi malas untuk belajar dan tergantung dengan orang lain.

Sejalan dengan apa yang disampaikan oleh Ayu Pande selaku guru Agama Hindu di SMAS Dharma Praja Denpasar (wawancara 19 Juni 2021) menyatakan bahwa mencontek merupakan budaya yang sulit dihindari apalagi dihilangkan dari siswa. Adanya teknologi yang berkembang seperti saat ini, perilaku mencontek siswa cenderung lebih canggih seakan-akan siswa tersebut dapat mengerjakan soal ujian sendiri atau mengerjakan tugas yang diberikan oleh guru. Pembelajaran daring saat ini memudahkan siswa untuk mengambil dan menyalin jawaban dari teman sehingga guru kesulitan untuk mengetahui siswa mana yang benar-benar telah kompeten dalam materi pelajaran tersebut. Perilaku ini tentu saja dapat membuat siswa malas belajar karena menganggap pasti mendapatkan bantuan dari temannya saat menghadapi ujian maupun saat mendapatkan tugas dari guru.

\section{Tidak Patuh Terhadap Arahan Guru}

Saat pembelajaran daring berlangsung sering dijumpai siswa yang tidak patuh terhadap arahan guru yaitu saat guru meminta untuk open video ketika menggunakan video conference dalam penyampaian materi ajar, siswa tidak menaatinya. Hal ini dapat mengganggu proses pembelajaran sehingga menjadi tidak efektif dan efisien. Guru Agama Hindu di SMAS Dharma Praja Denpasar berpendapat bahwa perilaku tidak patuh terhadap arahan guru memiliki keinginan atau kehendak yang kuat dalam hal memperlihatkan jati diri dari siswa tersebut. Sejalan dengan apa yang disampaikan oleh I Ketut Rumpyuk selaku guru Agama Hindu di SMAS Dharma Praja Denpasar (wawancara tanggal 21 Juni 2021) menyatakan bahwa peraturan sekolah maupun peraturan yang telah disepakati oleh guru dan siswa yang akan serta merta di langgar sebagai bentuk dari penunjukan eksistensinya di kelas sehingga hal ini tidak sesuai dengan nilai moral yang ditetapkan oleh guru atau orang 
dewasa. Sikap tidak patuh terhadap arahan guru sering muncul pada siswa yang memiliki keinginan untuk memperlihatkan jati dirinya saat pembelajaran berlangsung sehingga dapat mengalihkan perhatian guru.

Lebih lanjut I Ketut Rumpyuk menyampaikan bahwa sebab siswa tidak patuh terhadap arahan guru karena siswa tersebut tidak mengerti terhadap apa yang harus dilakukan karena daya tangkap siswa dalam berkomunikasi kurang, tidak memperhatikan guru, dan asyik dengan gadget dan teman sekelasnya. Selain itu siswa tersebut merasa kecewa terhadap guru karena guru kurang peka terhadap hasil karya atau sikap siswa, sehingga siswa tidak lagi mengikuti arahan guru dengan maksimal dan dapat dikatakan acuh tak acuh terhadap guru. Hal ini perlu kebijakan dari guru mengenai sikap siswa yang terkesan tidak memperdulikan guru dan dapat sebagai media introspeksi guru terhadap sikap dan hasil karya yang telah siswa kerjakan serta selesaikan.

\section{Membolos}

Hasil wawancara terhadap Guru Agama Hindu di SMAS Dharma Praja Denpasar, I Ketut Rumpyuk (wawancara 21 Juni 2021) berpendapat bahwa perilaku membolos memberikan kerugian bagi siswa itu sendiri dan guru sebagai pengampu mata pelajaran di kelas tersebut. Kerugian bagi guru yaitu guru memerlukan waktu untuk menasehati siswa yang bolos agar tidak mengulangi perbuatannya dan menasehati siswa lainnya agar tidak meniru perbuatan mengganggu tersebut sehingga waktu yang seharusnya dipergunakan oleh guru untuk mengajar menjadi terlewatkan karena menangani kenakalan siswa yaitu membolos.

Membolos merupakan hal yang lumrah terdengar dalam dunia pendidikan dari sejak jaman dahulu dan masih dilakukan pada masa kini di kalangan siswa remaja. Membolos saat pembelajaran daring adalah ketika siswa tidak hadir tanpa keterangan saat pembelajaran berlangsung melalui video conference dan siswa tidak melakukan absensi di google form maupun di google classroom. Menurut guru Agama Hindu di SMAS Dharma Praja Denpasar perilaku membolos ini terjadi karena faktor internal dan eksternal. Faktor internal adalah faktor yang ada di dalam diri siswa itu sendiri misalnya merasa tidak mampu mengikuti mata pelajaran tertentu sehingga memilih untuk tidak hadir tanpa keterangan yang jelas, dapat juga karena tidak berminat pada mata pelajaran yang bersangkutan dan merasa malu terhadap teman sekelas jika tidak dapat menjawab pertanyaan dan tugas yang diberikan oleh guru, akhirnya memilih untuk membolos. Faktor ekternal adalah faktor yang ada di luar diri siswa tersebut misalnya ajakan dari teman sekelas, jika tidak diikuti maka tidak diajak bergaul dan berdampak kepada tidak memiliki teman. Faktor eksternal ini sangat terkait dengan pergaulan siswa itu sendiri, jika siswa bergaul dengan siswa lain yang suka membolos maka perilaku ini akan menjerumuskannya. Saat terjadi hal ini maka guru akan menasehati siswa untuk tidak melakukan perilaku menyimpang ini sehingga waktu yang seharusnya dipergunakan guru untuk mengajar akan terhenti.

Hal itu sesuai dengan pendapat Mayer, dkk. (1993) yang menyatakan bahwa salah satu masalah yang muncul dari perilaku membolos yaitu guru kehilangan waktu untuk mengajar karena menasehati siswa yang membolos dan harus mengulang materi pelajaran tersebut di hari yang lain. Hal ini juga merugikan siswa itu sendiri karena perilaku ini sangat merugikan baik dari segi waktu, hilangnya minat untuk belajar, merasa malu dengan teman sekelas dan dapat mengurangi rasa percaya diri dari siswa tersebut yang berdampak kepada prestasi belajarnya.

\section{Persepsi Guru tentang Penyebab Kenakalan Siswa}

Persepsi guru menyebutkan bahwa ada 4 (empat) penyebab kenakalan siswa yaitu: kurangnya perhatian orang tua (pendidikan moral dan dukungan ekonomi), metode 
pembelajaran guru yang kurang bervariasi (monoton), bahasa yang digunakan guru sulit untuk dipahami siswa dan materi pelajaran terlalu banyak.

Peranan orang tua dalam memberikan perhatian kepada putra-putrinya merupakan hal yang sangat esensial dan penting untuk tumbuh kembang anak baik secara fisik maupun mental. Fungsi orang tua akan bertambah pada saat anak telah remaja. Pendampingan layaknya teman sangat dibutuhkan oleh remaja sehingga orang tua dapat menjadi contoh dalam pendidikan moral dan perilaku di masyarakat.

Faktor metode pembelajaran guru yang monoton menjadi penyebab dari perilaku mengganggu karena siswa menjadi kurang tertarik terhadap materi pembelajaran yang sedang dibahas atau disajikan. Siswa mencoba untuk keluar dari apa yang menurutnya kurang menarik dengan membahas atau mengalihkan pembicaraan di kelas dengan hal yang menurutnya lebih menarik. Hal itu sesuai dengan pendapat Dweretzky, (1990) yang menyatakan bahwa memang tidak dapat dipungkiri bahwa salah satu ciri dari remaja yaitu emosinya yang berubah-rubah.

Berkaitan dengan kedua penyebab tersebut, Ali \& Gracey (2013) menyatakan bahwa faktor lingkungan dapat menyebabkan timbulnya perilaku mengganggu. Artinya bahwa lingkungan yang tidak mendukung siswa akan menimbulkan munculnya perilaku-perilaku menyimpang. Penyebab pertama dan kedua tersebut merupakan kegagalan guru dalam menyediakan lingkungan belajar. Lingkungan belajar tidak dikondisikan dengan baik melalui metode dari guru yang bersangkutan.

Kurangnya persiapan dari siswa terhadap materi yang terlalu banyak untuk dikuasai mengakibatkan low self confident (kepercayaan diri rendah) sehingga niat untuk mencontek timbul. Hal itu sesuai dengan pendapat Danielsen, dkk. (2006) menyatakan bahwa memang permasalahan heavy course load (materi pelajaran yang berat dan banyak) sering menjadi penyebab umum dari perilaku mencontek. Konsekuensinya yaitu siswa memang menjadi malas dan kurang persiapan menghadapi tes yang kemudian timbul kurangnya kepercayaan diri pada siswa dalam menjawab soal-soal ujiannya. Oleh karena itu, benar bahwa materi yang terlalu banyak akan mengakibatkan kurangnya persiapan dari siswa, yang otomatis akan membunuh kepercayaan diri siswa dalam menjawab soal-soal ujian.

\section{Persepsi Guru dalam Mengatasi Tiap-Tiap Bentuk Kenakalan Siswa}

Beragam persepsi guru Agama Hindu mengenai cara dalam mengatasi kenakalan siswa, yaitu: pemberian model bagi siswa yaitu memberikan contoh siswa yang baik secara perilaku, sikap dan tanggung jawab, teguran verbal dapat berupa pemberian nasehat dan dampak jangka panjang jika tingkah laku menyimpang terus dilakukan tanpa niat untuk menghentikan, sanksi fisik berupa membersihkan kebun sekolah, membersihkan toilet, lari pagi dan lain sebagainya yang bermanfaat, perhatian khusus dapat berupa guru menyediakan waktu untuk mendengarkan cerita dan keluh kesah siswa di tempat yang nyaman sehingga siswa dapat mengutarakan sebab mengapa siswa tersebut melakukan perbuatan menyimpang dan perlahan menggiring siswa untuk memahami dampak buruk yang akan ditimbulkan jika perilaku menyimpang tersebut masih dilakukan, memanipulasi pemberian tugas dengan cara memberikan tugas yang mendidik kepada siswa di rumah misalnya selalu berdoa sebelum tidur, makan, dan bepergian, membersihkan tempat suci di rumah setiap hari, meditasi setiap pagi hari sebelum menjalani aktifitas, kemudian kegiatan tersebut di foto dan dikirimkan ke guru Agama Hindu.

Selain itu bentuk lain dalam mengatasi bentuk kenakalan siswa adalah memberikan aktivitas pengganti misalnya hal-hal yang berkaitan dengan materi pelajaran saat itu sehingga siswa dapat belajar dari pengalaman dan mulai mengetahui kesalahan sehingga diharapkan dapat berubah ke perilaku yang lebih baik, memanipulasi lokasi tempat duduk berupa siswa yang membuat gaduh, guru dapat meminta siswa tersebut untuk duduk di depan 
sehingga tidak ada kesempatan bagi siswa untuk bermain dan guru dapat dengan mudah memperhatikan perilakunya, memberikan pemahaman khusus mengenai tujuan belajar, tujuan hidup, menjadi siswa yang baik, menghormati orang tua dan guru dan lain sebagainya.

Saat pembelajaran daring, aktivitas pengganti ini dapat dalam bentuk pemberian tugas berupa pembuatan video yang terkait dengan materi pembelajaran dan dikumpulkan secara online kepada guru melalui plat form google classroom atau email dalam waktu yang telah ditentukan dan disepakati antara guru dan siswa. Pemberian kisi-kisi belajar berupa pokokpokok materi yang akan di bahas sehingga siswa telah mengetahui terlebih dahulu materi yang akan disampaikan oleh guru dengan upaya siswa tersebut menjadi lebih percaya diri sehingga kenakalan dapat dikurangi. Hal lain yang dapat dilakukan untuk mengatasi kenakalan siswa ialah berkomunikasi dengan orang tua sebagai upaya kerjasama yang efektif sehingga siswa merasa benar-benar diperhatikan baik di rumah maupun di sekolah, memberikan peraturan dapat berupa peraturan tertulis yang disepakati dengan siswa maupun peraturan lisan yang dapat siswa lakukan terus-menerus, memberikan pilihan baik buruk dengan memberikan cerita mengenai siswa yang berperilaku baik dengan siswa yang berperilaku kurang baik dan dampak terhadap masa depannya, memberikan motivasi, berkomunikasi secara pribadi dengan siswa dan dikembalikan kepada orang tua jika siswa tersebut sulit untuk dibina dan mengulang kesalahannya terus-menerus.

Memberikan aktivitas pengganti yang lebih menarik sebagai langkah untuk mengatasi kenakalan siswa dalam pembelajaran daring dilakukan oleh guru Agama Hindu di SMAS Dharma Praja Denpasar yaitu dengan memberikan aktivitas belajar yang menarik bagi siswa untuk mengatasi perilaku mengalihkan pembicaraan dari materi pelajaran atau diskusi. Aktivitas yang dipilih oleh guru Agama Hindu di SMAS Dharma Praja Denpasar yaitu aktivitas yang berhubungan dengan pembelajaran seperti penayangan video inspiratif, kuis berhadiah di akhir sesi pembelajaran, bermain peran yang dilakukan oleh siswa, dan pemberian tugas yang ditentukan oleh siswa itu sendiri dalam bentuk kelompok. Hal itu sesuai dengan pendapat Bentham (2004) yang menyatakan bahwa guru sebagai the man behind the guns atau orang utama yang merancang lingkungan belajar bagi siswa, harus selalu mengupayakan untuk menciptakan kondisi lingkungan belajar siswa yang nyaman dan menarik.

Merujuk pada pendapat tersebut tepat apabila guru berupaya memberikan aktivitas belajar yang menarik sehingga akan timbul rasa nyaman bagi siswa dan lebih tertarik lagi dengan konteks pembelajaran yang sudah direncanakan oleh guru. Selain itu, pendapat guru Agama Hindu di SMAS Dharma Praja Denpasar juga senada dengan pendapat Spergel (1971) yang menyatakan bahwa penggunaan sanksi dengan memberikan aktivitas pengganti yang positif sangat popular digunakan untuk memberikan pengetahuan kepada siswa bahwa ada kegiatan yang lebih positif dibandingkan berperilaku negatif. Merujuk pada pendapat tersebut, tepat sekali bahwa pemberian aktivitas pengganti berupa kegiatan positif akan sangat membantu siswa untuk tertarik lagi pada materi pelajaran atau diskusi.

\section{Berkomunikasi dengan Orang Tua Siswa}

Menggunakan cara berkomunikasi dengan orang tua siswa untuk mengatasi permasalahan perilaku mencontek, membolos sekolah, mencuri dan perilaku menyimpang siswa lainnya dalam mengikuti pembelajaran daring merupakan upaya guru Agama Hindu di SMAS Dharma Praja Denpasar. Orang tua yang bersangkutan dipanggil untuk hadir di sekolah kemudian guru menginformasikan bahwa anaknya sering melakukan perilaku mencontek dan perilaku mengganggu lainnya saat pembelajaran daring berlangsung. Tindakan tersebut sesuai dengan pendapat Nye (1974) yang menyatakan bahwa kehadiran orang tua sangat menentukan perilaku seorang anak. Artinya bahwa kehadiran orang tua di dalam kehidupan sehari-hari anak akan mampu menekan kemungkinan kenakalan pada 
anak. Hal itu disebabkan anak merasa mempunyai semacam pengawas sehingga anak akan berhati-hati dalam bersikap. Oleh sebab itu, berkomunikasi dengan orang tua siswa dapat dilakukan oleh seorang guru untuk mengurangi perilaku mengganggu siswa saat pembelajaran daring.

Perihal membolos dalam pembelajaran daring yaitu tidak hadir tanpa keterangan saat video conference menggunakan zoom atau google meet atau tidak melakukan absensi di google form, Guru Agama Hindu di SMAS Dharma Praja Denpasar juga melakukan kunjungan atau home visit ke rumah orang tua yang bersangkutan untuk mencari solusi bersama mengenai perilaku membolos yang dilakukan oleh anaknya. Tindakan itu sesuai dengan pendapat Gerrad (2003) yang secara serempak menyatakan bahwa penyertaan orang tua dalam pendidikan memang sangat berkontribusi positif dalam penyelesaian permasalahan perilaku membolos sekolah. Hal itu disebabkan siswa lebih terkontrol, baik oleh guru maupun orang tua. Kontrol tersebut akan menutupi celah siswa untuk membolos sekolah. Oleh sebab itu penyelesaian permasalahan membolos dengan melakukan home visit atau keterlibatan orang tua dalam pendidikan, memang sangat tepat.

Guru Agama Hindu di SMAS Dharma Praja Denpasar memberikan latihan pembiasaan pada siswa untuk mau jujur mengakui kesalahan. Siswa yang telah mau jujur mengakui kesalahannya kemudian diberikan pujian oleh guru Agama Hindu di SMAS Dharma Praja Denpasar. Tindakan itu sesuai dengan pendapat Bentham (2004) yang menyatakan bahwa pujian atau reward memang sesuatu yang paling efektif untuk mengatasi permasalahan perilaku. Pujian yang baik yaitu pujian yang diberikan dengan segera setelah perilaku yang positif dilakukan oleh siswa sehingga siswa mengetahui perilaku yang mendapatkan pujian dan mau mengulangi perilaku tersebut secara terus-menerus.

\section{Memberi Motivasi}

Guru Agama Hindu di SMAS Dharma Praja Denpasar memberikan motivasi untuk membesarkan hati siswa yang kerap membolos dengan memberikan pengetahuan mengani dampak buruk dari membolos dan ditambah upaya dari guru untuk selalu memperbaiki proses pembelajaran agar dapat menarik perhatian siswa sehingga membolos tidak lagi dilakukan. Hal itu senada dengan pendapat Gerrad (2003) yang menyatakan bahwa memang benar bahwa salah satu upaya untuk mengatasi permasalahan membolos yaitu dengan memberikan motivasi kepada siswa yang bersangkutan. Salah satu upaya motivasi itu dengan menyelenggarakan praktek pendidikan yang mampu memenuhi segala kebutuhan belajar siswa meliputi kenyamanan lingkungan belajar secara fisik maupun sosialpsikologis.

Oleh sebab itu memberikan motivasi kepada siswa dengan memperbaiki pembelajaran memang tepat dilakukan oleh guru guna mengatasi permasalahan perilaku membolos sekolah. Guru menggunakan cara private chat dengan siswa untuk mengatasi perilaku mencuri. Guru Agama Hindu di SMAS Dharma Praja Denpasar melakukan wawancara secara khusus dengan siswa untuk mencari penyebab perilaku mencuri ini dilakukan. Hal itu sesuai dengan pendapat Bentham (2004) menyatakan bahwa salah satu solusi yang dapat diterapkan dalam mengatasi permasalahan perilaku yaitu dengan cara private chat with student (wawancara secara khusus dengan siswa). Wawancara khusus bertujuan untuk mencari tahu permasalahan yang dihadapi siswa sehingga dapat ditemukan juga solusi permasalahan dengan bantuan guru. Oleh karena permasalahan perilaku mencuri ini kompleks,bahkan sebenarnya kapasitas masalah ini sangat berat bagi seorang siswa, maka penggunaan wawancara khusus ini sangat cocok diterapkan untuk mengasi permasalahan ini. 


\section{SIMPULAN}

Hasil penelitian terhadap persepsi guru Agama Hindu di SMAS Dharma Praja Denpasar tentang kenakalan siswa saat pembelajaran daring yaitu:

1) Kenakalan siswa adalah perilaku menyimpang dan melanggar peraturan sekolah yang dilakukan oleh siswa, sehingga mengganggu suasana belajar dan merugikan individu lain;

2) Bentuk kenakalan siswa dikategorikan menjadi 2, yaitu kenakalan siswa berupa perilaku mengganggu dan kenakalan serius. Perilaku mengganggu dipersepsikan beragam meliputi: tidak memperhatikan penjelasan guru, mencontek, mengalihkan pembicaraan dari materi pelajaran atau diskusi, tidak patuh terhadap arahan guru, sedangkan kenakalan serius siswa meliputi: perilaku membolos dan mencuri.

3) Beragam persepsi guru menyebutkan bahwa ada 4 penyebab kenakalan siswa yaitu: kurangnya perhatian orang tua (pendidikan moral dan dukungan ekonomi), metode pembelajaran guru yang kurang bervariasi (monoton), bahasa yang digunakan guru sulit untuk dipahami siswa dan materi pelajaran terlalu banyak.

4) Beragam persepsi guru mengenai cara mengatasi kenakalan siswa yaitu: pemberian model bagi siswa, teguran verbal, sanksi fisik, perhatian khusus, memanipulasi pemberian tugas, memberikan aktivitas pengganti, memanipulasi lokasi tempat duduk, memberikan pemahaman khusus, memberikan kisi-kisi belajar, berkomunikasi dengan orang tua, memberikan peraturan, memberikan pilihan baik dan buruk, memberikan motivasi, berkomukasi secara pribadi dengan siswa, dan dikembalikan kepada orang tua.

\section{DAFTAR PUSTAKA}

Arbuckle \& Little. 2004. Teacher's Perceptions and Management of Disrutive. Australian : Australian Journal of Educational \& Developmental Pshycology

Ali \& Gracey. 2013. Dealing With Student Disruptive Behavior In The Classroom. Learntech.lib.org

Bentham, S. 2004. A Teaching Assistant's Guide to Child Development and Psychology In The Classroom. London : Routledge Falmer

Cullen, K. 2011. Introducing Child Psychology. UK : Icon Books. Ltd

Danielsen, D. R., Simon, A.F,. \& Pavlick, R. 2016. The Culture of Cheating. Journal of Physician Assistant Education, 17 (I) : 23-29

Dweretzky, J.P. 1990. Introduction to Child Development. Mn. Minnesota: West Publising Company

Gregory. 2019. Family Relathionship. Westport : Greenwood Press

Gerrad, D., Burhans, A., \& Fair, J. 2013. Effective Truancy Prevention And Intervention. Minnesota : Wilder Research Center

Mayer, J.N. 1993. Perilaku Membolos Pada Siswa Remaja. Jakarta : Rineka Cipta

Nye, F.I. 1974. Family Relationship \& Delinguent Behavior. Westpost : Greenwood Press

Reed, D. \& Butler, C \& Legrice, L. 2009. A Local Case Study On Student's Perceptions of Truancy And Delinguent Behaviour. Sam Houst State University

Sarwono, S.W. 2011. Psikologi Remaja. Jakarta : Rajawali Pers

Slavin, E.R. 2016. Educational Psychology (Theory and Practice). United State of America : Pearson Education, Inc

Spergel, A.I.1971. Community Problem Solving (the delinguency example). Chicago : The University of Chicago Press.

Tejada, A.N. 1999. Facts for Families Childreen Who Steals. USA: American Academy of Child \& Adolescent Psychiatry

Veronika, A. 2018. Emosi \& Tingkah Laku Siswa. Psikolog : Personal Growth 
Wahyuningsih, Kompyang Sri. 2021. Problematika Pembelajaran Daring Di Masa Pandemi Covid-19 di SMA Dharma Praja Denpasar. UHN I Gusti Bagus Sugriwa Denpasar : Pangkaja : Jurnal Agama Hindu Vol.24 No.1

Willis, S.S. 2015. Remaja \& Masalahnya (Mengupas Berbagai Bentuk Kenakalan Remaja). Bandung : Alfabeta 